\title{
Cytogenetic characterisation of the razor shells Ensis directus (Conrad, 1843) and E. minor (Chenu, 1843) (Mollusca: Bivalvia)
}

\author{
Ana M. González-Tizón • Verónica Rojo • \\ Joaquín Vierna $\cdot K$. Thomas Jensen • \\ Emilie Egea $\cdot$ Andrés Martínez-Lage
}

Received: 19 October 2011/Revised: 12 January 2012/Accepted: 10 April 2012/Published online: 26 April 2012

(C) Springer-Verlag and AWI 2012

\begin{abstract}
The European razor shell Ensis minor (Chenu 1843) and the American E. directus (Conrad 1843) have a diploid chromosome number of 38 and remarkable differences in their karyotypes: E. minor has four metacentric, one metacentric-submetacentric, five submetacentric, one subtelocentric and eight telocentric chromosome pairs, whereas $E$. directus has three metacentric, two metacentric-submetacentric, six submetacentric, six subtelocentric and two telocentric pairs. Fluorescent in situ hybridisation (FISH) using a major ribosomal DNA probe located the major ribosomal genes on one submetacentric chromosome pair in both species; FISH with a $5 \mathrm{~S}$ ribosomal DNA (5S rDNA) probe rendered one chromosomal (weak) signal for $E$. minor and no signal for $E$. directus, supporting a more dispersed organisation of $5 \mathrm{~S}$ rDNA compared to the major ribosomal genes. The vertebrate telomeric sequence $(\text { TTAGGG })_{n}$ was located on both ends of each chromosome, and no interstitial signals were detected. In this work, a comparative karyological analysis was also performed between the four Ensis species analysed revealing that the three European species studied so far, namely
\end{abstract}

Communicated by Heinz-Dieter Franke.

A. M. González-Tizón ( ()$\cdot$ V. Rojo · J. Vierna ·

A. Martínez-Lage

Department of Cell and Molecular Biology,

Universidade da Coruña, A Fraga 10, 15008 La Coruña, Spain

e-mail: hakuna@udc.es

\section{K. T. Jensen}

Marine Ecology, Department of Bioscience, Aarhus University, Ole Worms Allé 1, Building 1135, 8000 Aarhus C, Denmark

E. Egea

Centre d'Océanologie de Marseille, Station Marine d'Endoume, Chemin de la Batterie des Lions, 13007 Marseille, France
E. minor, E. siliqua (Linné 1758) and E. magnus Schumacher 1817 show more similarities among them than compared to the American species E. directus. In addition, clear karyotype differences were found between the morphologically similar species E. minor and E. siliqua.

Keywords Razor shells - Karyotype · FISH · 18S-5.8S-28S rDNA · 5S rDNA · Telomeric sequence

\section{Introduction}

The genus Ensis Schumacher 1817 (Mollusca: Bivalvia: Pharidae) is composed of about 12 extant species that live on fine sand, silt or mud bottoms off the European, African and American coasts. In Europe, four species are native, E. ensis (Linné 1768), E. magnus Schumacher 1817 [syn. E. arcuatus (Jeffreys 1865)], E. minor (Chenu 1843) and E. siliqua (Linné 1758) and one introduced, E. directus (Conrad 1843) [syn. E. americanus (Gould 1870)]. This species was introduced to the German Bight at the end of the $1970 \mathrm{~s}$ from Atlantic North America, probably through ballast water (Cosel et al. 1982). In European coastal waters, the distribution areas of the different Ensis species are mostly overlapping and there are few areas occupied by only one species (Cosel 2009) though E. directus prefers brackish waters. The European E. minor has often been confused with its homonym E. minor Dall 1899 (which is native to the SE United States), although they constitute different species. Additional taxonomic confusion is due to the fact that both European E. minor and E. siliqua are very similar in terms of shell morphology. Cosel (2009) states "E. minor was frequently treated under the name E. siliqua or as a subspecies of that taxon; however, along the Atlantic coast the two species occur sympatrically with 
only very few possible intergrades which occasionally were found at the south coast of Brittany (Pl. 8f-k) and also a few at Ile de Ré, Charente Maritime. They are looking superficially like E. minor but mostly have the rounded posterior cross-section of E. siliqua ( $\mathrm{Pl}$. 8e). Only molecular research will elucidate this".

The two species studied in this work are distributed as follows: E. minor from British North Sea coast from the east coast of Scotland to southern England, The Netherlands, and the Channel; European Atlantic coast from the NW part of Wales southward to North Morocco and throughout the Mediterranean. The introduced E. directus is now well established in Europe and occurs from Denmark to France, England and Sweden (Cosel 2009).

Whereas recent molecular analyses have been performed in a number of Ensis (Varela et al. 2007, 2009; Vierna et al. 2009, 2010, 2011), there is only one report about karyotypes of these species (specifically only in E. magnus and E. siliqua by Fernández-Tajes et al. 2008). It is worthwhile to mention that there are more than 20,000 different molluscan species worldwide distributed in aquatic habitats, and only about 200 species have been cytogenetically studied (i.e. karyotyped). This is due to the fact that cytogenetic studies of molluscs are usually complicated because the difficulties derived of the very low mitotic index in adult tissues and the problems to gain higher mitotic indexes. Recent articles (since year 2000) dealing about cytogenetic characterisation of commercial marine molluscs have been performed in different species of mussels (Vitturi et al. 2000; Martínez-Lage et al. 2002; Iqbal et al. 2008; Pérez-García et al. 2010, 2011), clams (González-Tizón et al. 2000; Martínez et al. 2002; Plohl et al. 2002; Hurtado and Pasantes 2005; Leitao et al. 2006; Wang and Guo 2007, 2008), razor shells (Fernández-Tajes et al. 2003, 2008), oysters (Xu et al. 2001; Cross et al. 2005; Wang et al. 2005a, b; Huang et al. 2007a, b; Zhang et al. 2007), cockles (Leitao et al. 2006), and pectinids (Pauls and Afonso 2000: López-Piñón et al. 2005; Odierna et al. 2006; Huang et al. 2007a, b; Zhang et al. 2008).

Cytogenetic analyses are important as they provide information about the number and morphology of chromosomes, the differential distribution of euchromatinheterochromatin regions, the occurrence of chromosomal re-arrangements along evolution, phylogenetic relatedness between taxa, etc., and they help to clarify species status, which is extremely important in conservation biology. Therefore, they can be applicable in aquaculture as cytogenetic techniques, mainly FISH, are a significant part of genomic research to facilitate the construction of linkage maps, which are useful to identify loci of interest in economic marine species.

In the present study, we describe the chromosome number and morphology, and the location of the major ribosomal loci (18S-ITS1-5.8S-ITS2-28S) and the telomeric sequences in E. minor and E. directus. The location of $5 \mathrm{~S}$ ribosomal DNA (5S rDNA) in E. minor is also provided. In addition, we perform a comparative karyological analysis among E. minor, E. directus, E. magnus and $E$. siliqua in order to infer phylogenetic relationships based on karyotype differences and to clarify E. minorE. siliqua taxonomic status.

\section{Materials and methods}

\section{Biological material}

Specimens of $E$. minor were collected from La Capte $\left(43^{\circ} 02^{\prime} \mathrm{N}, 6^{\circ} 09^{\prime} \mathrm{E}\right)$ and Bandol $\left(43^{\circ} 08^{\prime} \mathrm{N}, 5^{\circ} 46^{\prime} \mathrm{E}\right)$ (both localities on the Eastern Gulf of Lion, France), and those of E. directus were caught in Vester Vedsted $\left(55^{\circ} 17^{\prime} \mathrm{N}\right.$, $8^{\circ} 38^{\prime} \mathrm{E}$ ) (Denmark). In the laboratory, animals were fed with a suspension of Isochrysis galbana and Tetraselmis sp. microalgae for 10-15 days. Specimens were identified according to Cosel (2009).

\section{Chromosome preparation}

Metaphases were obtained from gill tissue of adult specimens after treatment with colchicine solution $(0.005 \%)$ for 6-8 h. Gills were dissected and treated twice with $0.56 \%$ $\mathrm{KCl}$ solution for $15 \mathrm{~min}$. After fixation in ethanol-glacial acetic acid (3:1), cells were dissociated in $45 \%$ acetic acid and dropped onto slides heated at $43{ }^{\circ} \mathrm{C}$. Metaphases were stained with $4 \%$ Giemsa in phosphate buffer pH 6.8 and photographed using a Nikon Microphot-FXA microscope equipped with a NIS-Elements D 3.10 software and a digital camera DS-Qi1Mc.

\section{Karyotyping}

Chromosome measurements were performed using the Leica Chantal image analysis software system described in González-Tizón et al. (2000). Chromosome measurements were carried out in 12 metaphases from 12 individuals in both species. Mean value of the length of the chromosome arms and the mean value for their total chromosome lengths were calculated for each of the chromosome pairs. The relative length $(100 \times$ chromosome length/total haploid length), the centromeric index $(100 \times$ length of short arm/total chromosome length), the mean value and the standard error (standard deviation/number of individuals) ${ }^{1 / 2}$ of the relative lengths and centromeric indices were also calculated. Karyotypes were arranged by decreasing size and classified according to the centromeric index, following the nomenclature of Levan et al. (1964). 
Fluorescent in situ hybridisation (FISH)

Chromosomal location of rDNA loci was performed by FISH as described in González-Tizón et al. (2000). The DNA probe pDM 238 from Drosophila melanogaster (Roiha et al. 1981), containing the repeat unit 18S-5.8S-28S rDNA, was labelled by nick translation with digoxigenin11-dUTP (Roche) for chromosome mapping of major ribosomal genes. The $5 \mathrm{~S}$ rDNA probe was obtained by PCR using the primers 5S-Univ-F (5'-ACCGGTGTTTTC AACGTGAT) and 5S-Univ-R (5'-CGTCCGATCACCG
AAGTTAA) designed by Vierna et al. (2009). These primers had opposite orientations and were separated by $3 \mathrm{bp}$. The probe was labelled by PCR with digoxigenin-11dUTP (Roche).

Telomeric FISH was carried out as in Plohl et al. (2002) with the (TTAGGG) 22 probe labelled with digoxigenin by a standard PCR procedure. Slides were counterstained with propidium iodide (50 ng/mL antifade) and visualised and photographed using a Nikon Microphot-FXA microscope equipped with a NIS-Elements D 3.10 software and a digital camera DS-Qi1Mc.

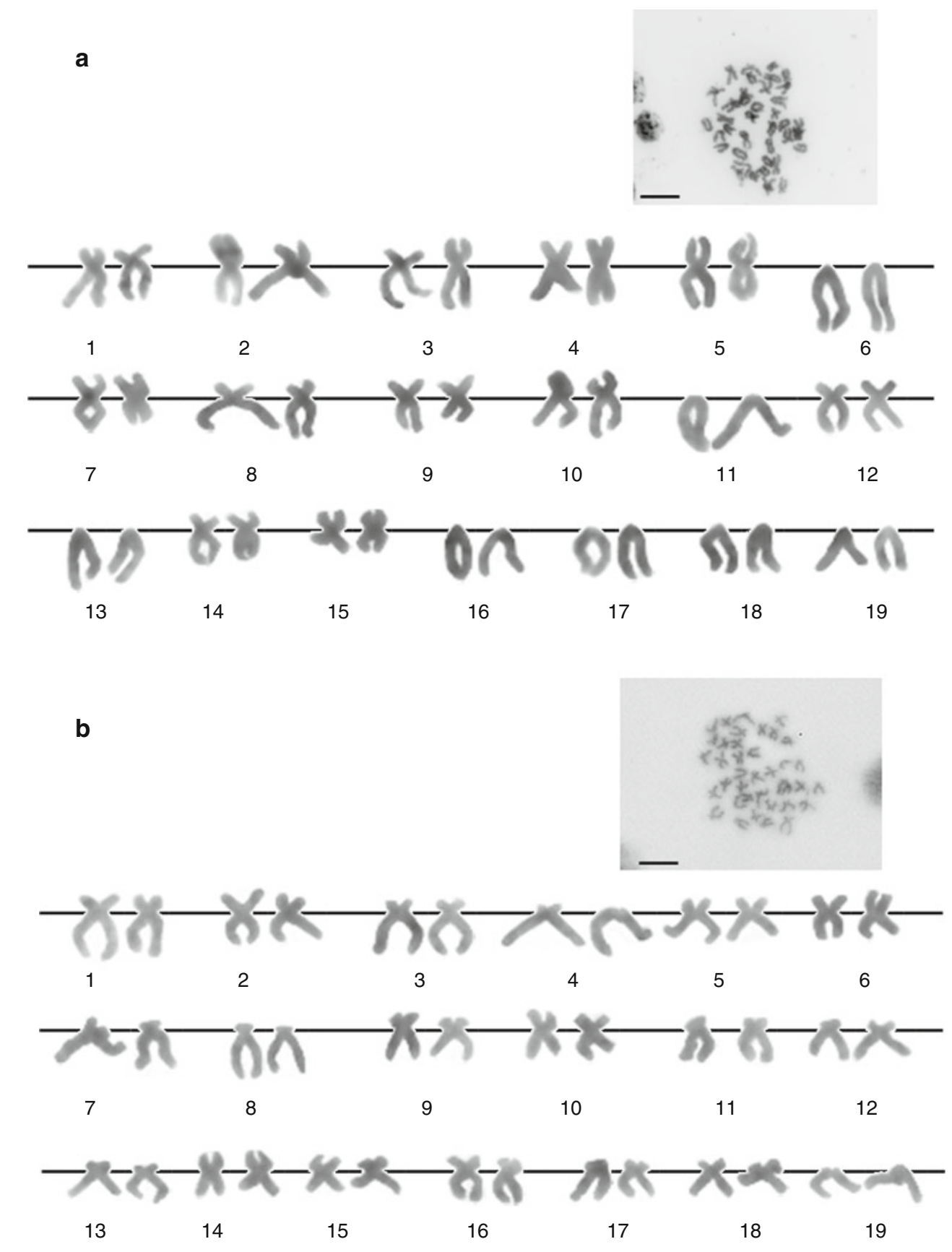

Fig. 1 Karyotypes of a Ensis minor and b E. directus (both $2 n=38$ chromosomes). Bar $10 \mu \mathrm{m}$ 


\section{Results}

Analysis of 38 metaphases from 15 specimens of $E$. minor and 42 metaphases from 12 specimens of $E$. directus revealed a diploid chromosome number for each species of $2 n=38$ (Fig. 1a, b). For karyotyping, ten well-spread metaphases were paired on the basis of chromosome size and centromere position and used for chromosome measurements and classification. In E. minor, relative length varied from 3.40 to 6.99 , and in E. directus, it ranged from 3.46 to 6.93 (Table 1). The karyotype of E. minor consisted of four metacentric chromosome pairs, one metacentricsubmetacentric, five submetacentric, one subtelocentric and eight telocentric (Figs. 1a, 3a). The species E. directus had three metacentric, two metacentric-submetacentric, six submetacentric, six subtelocentric and two telocentric chromosome pairs (Figs. 1b, 3b).

In both species, FISH using a 18S-ITS1-5.8S-ITS2-28S probe revealed the location of a major ribosomal locus on the short arm of one submetacentric chromosome pair at an interstitial position (Figs. 2a, b, 3a, b). Telomeric signals appeared at the end of all chromosomes on both Ensis species (Fig. 2c, d), and a signal for the 5S rDNA gene family was located at a subtelomeric region of one medium-size telocentric chromosome pair in E. minor
(Fig. 2e), whereas E. directus did not show fluorescent signal after $5 \mathrm{~S}$ rDNA hybridisation. In our previous studies (Vierna et al. 2009, 2011), PCR amplifications of 5S rDNA in $E$. directus generated multiple fragments, with sizes ranging between 406 and $739 \mathrm{bp}$, corresponding to $5 \mathrm{~S}$ rDNA variants that differed in the length of the nontranscribed spacer region (NTS). Additional PCR products were identified as dimer and trimer sequences formed by two and three contiguous monomers, respectively. The species E. minor was not studied in these reports, but differences in 5S rDNA organisation are not to be expected among E. minor and the other European species analysed (i.e. E. ensis, E. siliqua and E. magnus).

\section{Discussion}

This study reveals that $E$. minor and $E$. directus have a diploid chromosome number of 38 chromosomes, which is coincident with those previously reported on their congenerics E. magnus and E. siliqua (Fernández-Tajes et al. 2008), and with the majority of the karyotypes studied within the Heterodonta bivalves. However, there are some exceptions as Kidderia minuta (Thiriot-Quievreux et al. 1988a), Lasaea australis (Thiriot-Quievreux 1992), Spaherium

Table 1 Chromosome measurements and classification

\begin{tabular}{|c|c|c|c|c|c|c|c|}
\hline \multicolumn{4}{|c|}{ Ensis minor } & \multicolumn{4}{|c|}{ Ensis directus } \\
\hline & RL & $\mathrm{CI}$ & Class & & RL & $\mathrm{CI}$ & Class \\
\hline 1 & $6.99 \pm 0.06$ & $32.73 \pm 0.61$ & $\mathrm{sm}$ & 1 & $6.93 \pm 0.03$ & $26.18 \pm 0.79$ & $\mathrm{sm}$ \\
\hline 2 & $6.61 \pm 0.03$ & $35.52 \pm 0.76$ & $\mathrm{sm}$ & 2 & $6.56 \pm 0.07$ & $41.09 \pm 0.37$ & $\mathrm{~m}$ \\
\hline 3 & $6.36 \pm 0.03$ & $33.74 \pm 0.26$ & $\mathrm{sm}$ & 3 & $6.24 \pm 0.06$ & $29.43 \pm 0.41$ & $\mathrm{sm}$ \\
\hline 4 & $6.24 \pm 0.04$ & $31.36 \pm 0.52$ & $\mathrm{sm}$ & 4 & $6.16 \pm 0.04$ & $22.53 \pm 0.57$ & st \\
\hline 5 & $6.05 \pm 0.03$ & $39.88 \pm 0.56$ & $\mathrm{~m}$ & 5 & $5.99 \pm 0.11$ & $33.80 \pm 0.60$ & $\mathrm{sm}$ \\
\hline 6 & $5.88 \pm 0.08$ & $0.11 \pm 0.01$ & $\mathrm{t}$ & 6 & $5.74 \pm 0.05$ & $37.85 \pm 0.37$ & $\mathrm{~m}-\mathrm{sm}$ \\
\hline 7 & $5.75 \pm 0.03$ & $37.95 \pm 0.65$ & $\mathrm{~m}-\mathrm{sm}$ & 7 & $5.66 \pm 0.07$ & $33.28 \pm 0.79$ & $\mathrm{sm}$ \\
\hline 8 & $5.39 \pm 0.05$ & $0.12 \pm 0.01$ & $\mathrm{t}$ & 8 & $5.60 \pm 0.04$ & $8.16 \pm 0.35$ & $\mathrm{t}$ \\
\hline 9 & $5.29 \pm 0.06$ & $39.61 \pm 0.63$ & $\mathrm{~m}$ & 9 & $5.31 \pm 0.03$ & $22.58 \pm 0.84$ & st \\
\hline 10 & $5.22 \pm 0.05$ & $33.46 \pm 0.51$ & $\mathrm{sm}$ & 10 & $5.25 \pm 0.06$ & $38.84 \pm 0.30$ & $\mathrm{~m}$ \\
\hline 11 & $5.11 \pm 0.05$ & $0.12 \pm 0.01$ & $\mathrm{t}$ & 11 & $5.17 \pm 0.04$ & $22.56 \pm 0.47$ & st \\
\hline 12 & $4.87 \pm 0.08$ & $17.75 \pm 1.48$ & st & 12 & $5.02 \pm 0.04$ & $21.66 \pm 0.71$ & st \\
\hline 13 & $4.84 \pm 0.04$ & $2.65 \pm 0.84$ & $\mathrm{t}$ & 13 & $4.87 \pm 0.04$ & $38.06 \pm 0.72$ & $\mathrm{~m}-\mathrm{sm}$ \\
\hline 14 & $4.78 \pm 0.07$ & $38.53 \pm 0.58$ & $\mathrm{~m}$ & 14 & $4.66 \pm 0.06$ & $38.56 \pm 0.58$ & $\mathrm{~m}$ \\
\hline 15 & $4.60 \pm 0.08$ & $39.98 \pm 0.62$ & $\mathrm{~m}$ & 15 & $4.55 \pm 0.05$ & $30.12 \pm 1.24$ & $\mathrm{sm}$ \\
\hline 16 & $4.53 \pm 0.03$ & $0.14 \pm 0.01$ & $\mathrm{t}$ & 16 & $4.41 \pm 0.04$ & $23.33 \pm 0.96$ & st \\
\hline 17 & $4.23 \pm 0.04$ & $0.15 \pm 0.01$ & $\mathrm{t}$ & 17 & $4.22 \pm 0.03$ & $14.38 \pm 0.95$ & st \\
\hline 18 & $3.87 \pm 0.04$ & $0.16 \pm 0.01$ & $\mathrm{t}$ & 18 & $4.20 \pm 0.04$ & $27.23 \pm 0.66$ & $\mathrm{sm}$ \\
\hline 19 & $3.40 \pm 0.05$ & $1.46 \pm 0.41$ & $\mathrm{t}$ & 19 & $3.46 \pm 0.06$ & $7.67 \pm 0.34$ & $\mathrm{t}$ \\
\hline
\end{tabular}

$R L$ relative length, $C I$ centromeric index, Class classification, $m$ metacentric, $s m$ submetacentric, $s t$ subtelocentric, $t$ telocentric 

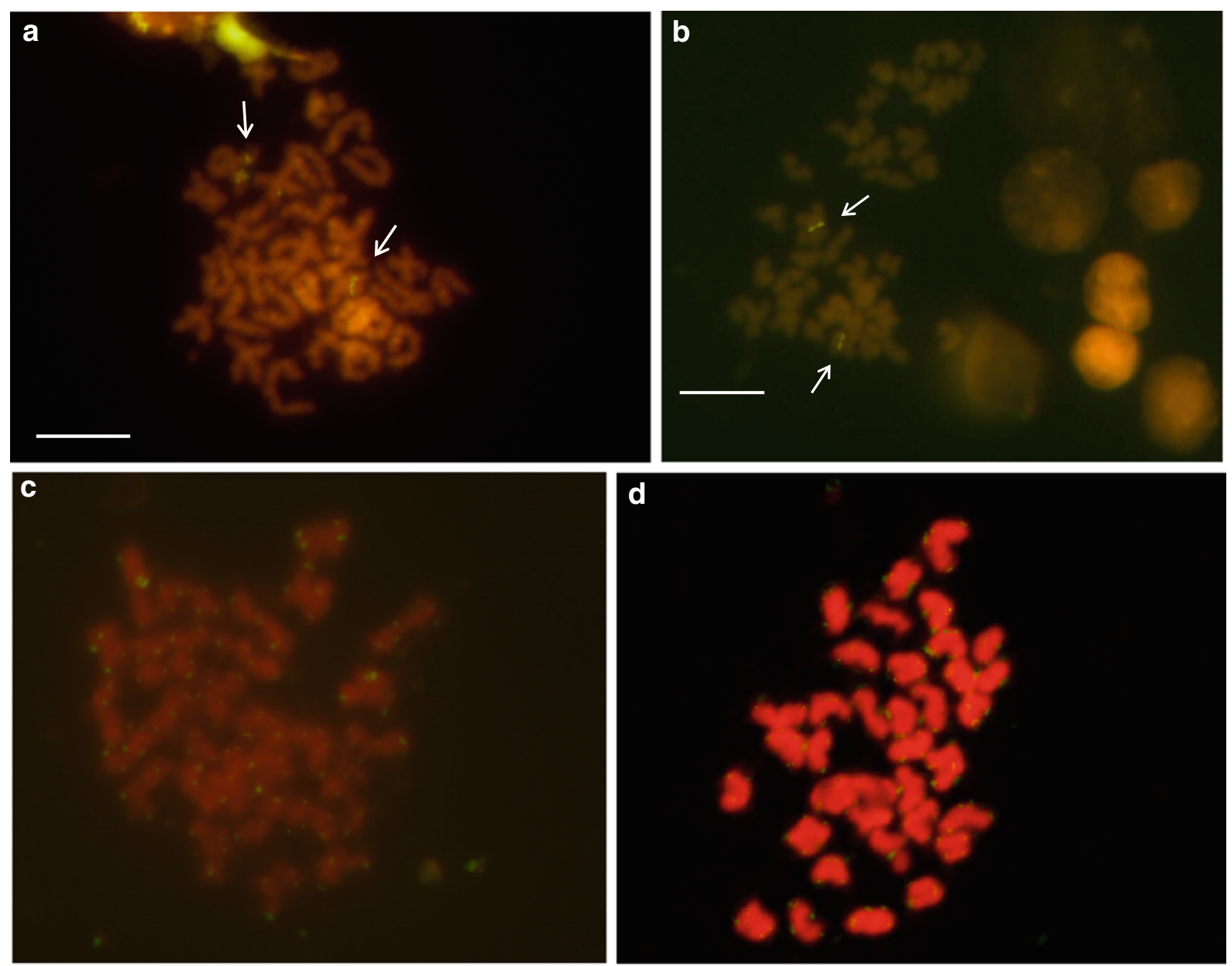

d

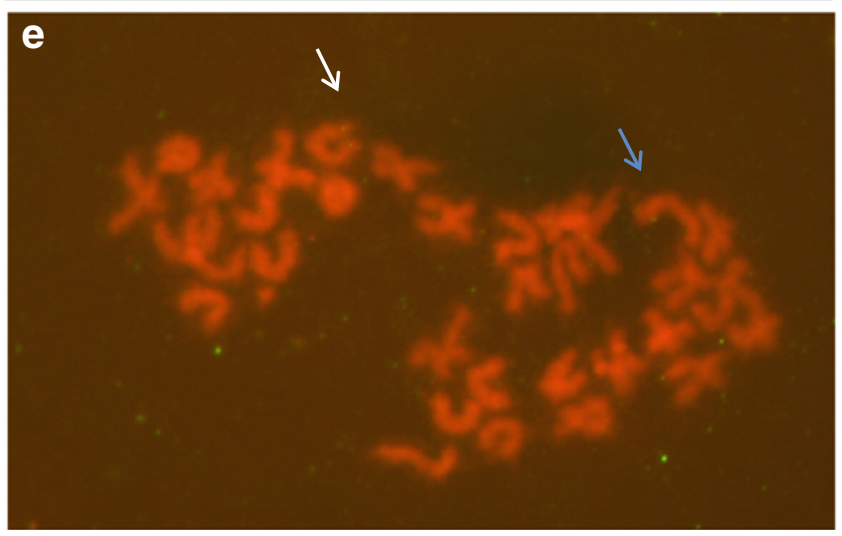

Fig. 2 Metaphases of Ensis minor after a FISH with an 18S-ITS15.8S-ITS2-28S ribosomal DNA probe, $\mathbf{c}$ FISH with a telomeric probe, e FISH with a $5 \mathrm{~S}$ ribosomal DNA probe. Metaphases of E. directus

after b FISH with an 18S-ITS1-5.8S-ITS2-28S ribosomal DNA probe, d FISH with a telomeric probe. Bar $10 \mu \mathrm{m}$

corneum (Petkeviciute et al. 2006) and Cyclinia sinensis (Wang et al. 2001), all of them with $2 n=36$ chromosomes, Cyclocardia astartoides (Thiriot-Quievreux et al. 1990) with $2 n=30$, and some Lasaea species with different levels of

polyploidy (Thiriot-Quievreux et al. 1988b, 1989; Ó Foighil and Thiriot-Quievreux 1999).

The karyotypes of E. minor and E. directus have telocentric pairs, which is not very usual in Heterodonta. 
Fig. 3 Idiograms of a Ensis minor, b E. directus, c $E$. magnus and $\mathbf{d}$ E. siliqua. Black refill represents the location of the 18S-ITS1-5.8S-ITS2-28S ribosomal loci. c, d Data taken from Fernández-Tajes et al. (2008)
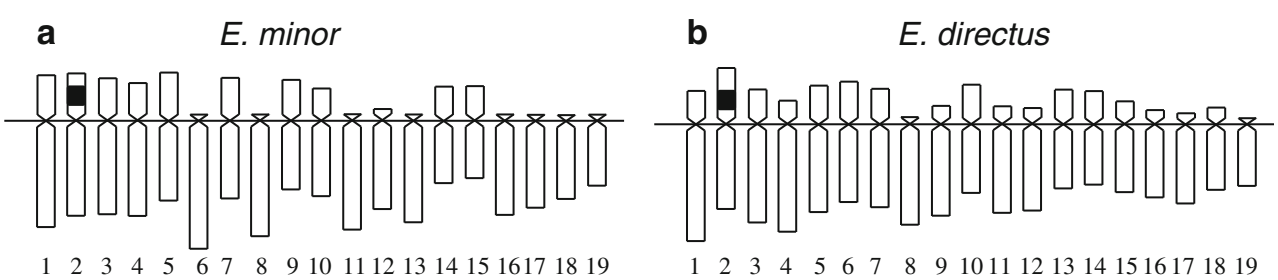

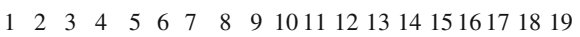

d E. siliqua

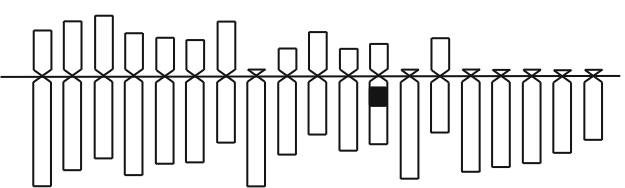

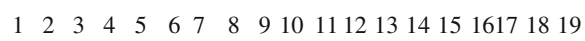

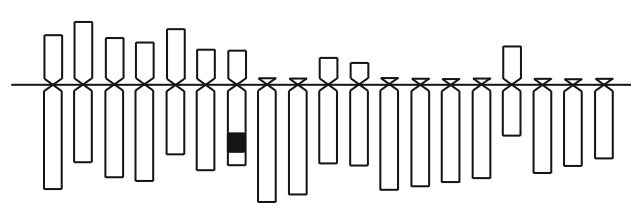

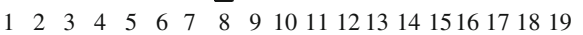

To our knowledge, only the karyotypes of 29 Heterodonta species reported so far belonging to 12 different families have telocentric chromosomes (Table 2). The number of telocentric pairs varies from one in Donax trunculus (Martínez et al. 2002), Lasaea colmani (Ó Foighil and Thiriot-Quievreux 1999), Scrobicularia plana (Cornet and Soulard 1989), Sinonovacula constricta (Wang et al. 1998), and Ruditapes aureus (=Venerupis aurea) (Borsa and Thiriot-Quievreux 1990; Carrilho et al. 2011) to 19 (all the complement) in Mulinia lateralis (Wang and Guo 2008).

The comparative analysis of Ensis karyotypes shows that the diploid chromosome number is the same for the four species and that the number of telocentrics is higher in the European ones than in the American species (nine pairs in E. siliqua, eight in E. minor and seven in E. magnus, whereas $E$. directus has only two telocentric pairs). In the four species, the number of metacentric and submetacentric pairs is similar: 11 in E. directus and E. magnus and 10 in E. minor and E. siliqua, being the major differences in the number of subtelocentrics: one pair in E. minor and E. magnus and six pairs in E. directus, whereas E. siliqua has no subtelocentrics. These differences lead to karyotypes with numbers of chromosome arms of: 72 in $E$. directus, 62 in E. magnus, 60 in E. minor and 58 in E. siliqua, this representing a major divide between the American species (E. directus) and the European species (E. magnus, E. siliqua and E. minor). According to White (1978) who pointed out that karyotypes with higher proportion of metacentrics are generally considered as more primitive (plesiomorphic) and show relative more chromosome stability than karyotypes with few metacentric chromosomes (apomorphic), the results obtained for the Ensis species suggest that $E$. directus is the species with the most ancestral karyotype, whereas the karyotypes of the native European species may be more recent. Differences in the number of bi-armed and mono-armed chromosomes lead us to think that structural re-arrangements (involving loss of chromosomal arms and emergence of telocentrics, fusion of telocentric chromosomes and reciprocal or robertsonian translocations, or inversions) could have occurred during the evolution of Ensis species, as suggested Wang and Guo (2004) for Pectinidae species and Wang and Guo (2008) for M. lateralis.

These results confirm E. siliqua and E. minor as separate species, clarifying their taxonomic status, and may be very useful in future programmes on aquaculture and conservation of these species.

Concerning the major ribosomal loci, these have been mapped using FISH in 10 Heterodonta species: Cerastoderma edule (Insua et al. 1999), Donax trunculus (Martínez et al. 2002), Solen marginatus (Fernández-Tajes et al. 2003), Dosinia exoleta (Hurtado and Pasantes 2005), Mercenaria mercenaria (Wang and Guo 2007), E. magnus and E. siliqua (Fernández-Tajes et al. 2008) (Fig. 3c, d), M. lateralis (Wang and Guo 2008) and Tapes rhomboides and V. aurea (Carrilho et al. 2011). All of them showed one major ribosomal locus, except $S$. marginatus (FernándezTajes et al. 2003) and M. lateralis (Wang and Guo 2008), which had two loci. The four Ensis species showed only one chromosomal interstitial signal on one submetacentric pair (Fig. 3). In E. minor and E. directus, the fluorescent signal appeared interstitially located on the $\mathrm{p}$ arm of chromosome number 2, whereas in E. magnus and E. sili$q u a$, the signal is on q arm of chromosome number 12 and 7 , respectively. These differences in location of major ribosomal genes could be explained by translocations, as suggested Wang and Guo (2004) for pectinids. In E. minor and $E$. directus, FISH signals were stronger on one of the homologous chromosomes than on the other, which, as pointed out by Xu et al. (2001) is probably due to random variation in FISH or the differences (loss or gain) in the number of rDNA repeats.

The FISH experiments using 5S rDNA probes were only obtained until now in three species belonging to the subclass Heterodonta, the cockle C. edule (Insua et al. 1999), which revealed nine hybridisation signals, and the clams 
Table 2 List of Heterodonta species with telocentric chromosomes

\begin{tabular}{|c|c|c|c|}
\hline $\begin{array}{l}\text { Taxa an diploid chromosome } \\
\text { number }\end{array}$ & $\begin{array}{l}\text { No. of telocentric } \\
\text { pairs }\end{array}$ & Authors & $\begin{array}{l}\text { No. of } 18 \mathrm{~S}-28 \mathrm{~S} \text { loc } \\
\text { (FISH) }\end{array}$ \\
\hline \multicolumn{4}{|l|}{ Family CARDIIDAE } \\
\hline Cerastoderma edule $(2 n=38)$ & 3 & $\begin{array}{l}\text { Insua and Thiriot-Quievreux (1992), } \\
\text { Insua et al. (1999) }\end{array}$ & 1 \\
\hline \multicolumn{4}{|l|}{ Family CARDITIDAE } \\
\hline Cyclocardia astartoides $(2 n=30)$ & 10 & Thiriot-Quievreux et al. (1990) & \\
\hline \multicolumn{4}{|l|}{ Family CYAMIIDAE } \\
\hline Kidderia bisulcata $(2 n=38)$ & 5 & Thiriot-Quievreux et al. (1988a) & \\
\hline Kidderia minuta $(2 n=36)$ & 5 & Thiriot-Quievreux et al. (1988a) & \\
\hline \multicolumn{4}{|l|}{ Family DONACIDAE } \\
\hline Donax trunculus $(2 n=38)$ & 1 & Martínez et al. (2002) & 1 \\
\hline \multicolumn{4}{|l|}{ Family LASAEIDAE } \\
\hline Lasaea australis $(2 n=36)$ & 5 & Thiriot-Quievreux (1992) & \\
\hline Lasaea colmani $(2 n=40)$ & 1 & Ó Foighil and Thiriot-Quievreux (1999) & \\
\hline Lasaea consanguinea $(2 n=100-120)^{\mathrm{a}}$ & 4 & Thiriot-Quievreux et al. (1988b) & \\
\hline Lasaea rubra $(n=63-340)^{\mathrm{a}}$ & 9 & Thiriot-Quievreux et al. (1989) & \\
\hline \multicolumn{4}{|l|}{ Family MACTRIDAE } \\
\hline Mulinia lateralis $(2 n=38)$ & 19 & Wang and Guo (2008) & 2 \\
\hline \multicolumn{4}{|l|}{ Family PHARIDAE } \\
\hline Ensis directus $(2 n=38)$ & 2 & Present work & 1 \\
\hline Ensis magnus $($ E. arcuatus $)(2 n=38)$ & 7 & Fernández-Tajes et al. (2008) & 1 \\
\hline Ensis minor $(2 n=38)$ & 8 & Present work & 1 \\
\hline Ensis siliqua $(2 n=38)$ & 9 & Fernández-Tajes et al. (2008) & 1 \\
\hline \multicolumn{4}{|l|}{ Family SEMELIIDAE } \\
\hline Scrobicularia plana $(2 n=38)$ & 1 & Cornet and Soulard (1989) & \\
\hline \multicolumn{4}{|l|}{ Family SOLECURTIDAE } \\
\hline Sinonovacula constricta $(2 n=38)$ & 1 & Wang et al. (1998) & \\
\hline \multicolumn{4}{|l|}{ Family SOLENIDAE } \\
\hline Solen grandis $(2 n=38)^{\mathrm{b}}$ & 2 & Sun et al. (2003) & \\
\hline Solen linearis $(2 n=38)^{\mathrm{b}}$ & 2 & Chen et al. (2008) & \\
\hline Solen marginatus $(2 n=38)$ & 2 & Fernández-Tajes et al. (2003) & 2 \\
\hline \multicolumn{4}{|l|}{ Family TEREDINIDIAE } \\
\hline Teredo utriculus $(2 n=38)$ & 14 & Vitturi et al. (1983) & \\
\hline \multicolumn{4}{|l|}{ Family VENERIDAE } \\
\hline Chamelea gallina $(2 n=38)$ & 4 & Corni and Trentini (1986) & \\
\hline Circe scripta $(2 n=38)$ & 3 & Ebied and Aly (2004) & \\
\hline Cyclina sinensis $(2 n=36)^{\mathrm{b}}$ & 11 & Wang et al. (2001) & \\
\hline Meretrix meretrix $(2 n=38)^{\mathrm{b}}$ & 3 & Wu et al. (2002) & \\
\hline Ruditapes aureus (V. aurea) $(2 n=38)$ & 1 & $\begin{array}{l}\text { Borsa and Thiriot-Quievreux (1990), } \\
\text { Carrilho et al. (2011) }\end{array}$ & 1 \\
\hline Ruditapes decussatus $(2 n=38)$ & 5 & Ebied and Aly (2004) & \\
\hline Tapes rhomboides $(2 n=38)$ & 4 & Carrilho et al. (2011) & 1 \\
\hline Venerupis rhomboides $(2 n=38)$ & 3 & Insua and Thiriot-Quievreux (1992) & \\
\hline Venus verrucosa $(2 n=38)$ & 4 & Ebied and Aly (2004) & \\
\hline
\end{tabular}

a Different levels of polyploidy

b In Chinese; only abstract in English 
T. rhomboides and V. aurea (Carrilho et al. 2011) with one signal. In this present work, we reported the occurrence of at least one $5 \mathrm{~S}$ rDNA array containing a sufficient number of repeats to yield a (weak) fluorescent signal in E. minor. Even though in bivalve species, it is usual that some of the metaphases analysed do not yield any FISH signal (as it has previously been described by Wang et al. $(2005 \mathrm{a}, \mathrm{b})$ in an oyster), the absence of a 5S rDNA signal, compared to the clear signal obtained with the major ribosomal genes probe, may well be explained by differences in the genomic organisation of these gene families. Thus, if $5 \mathrm{~S}$ rDNA is much more dispersed in the genome of Ensis razor shells, compared to the major ribosomal genes (as suggested by Vierna et al. 2010), then FISH using that probe should produce a so weak signal which may probably be invisible. Differences in the genomic organisation between both species may be explained by the phylogenetic distance between American and European species, as revealed by the karyotypes (this study), shell morphology (Cosel 2009) and the ITS1-5.8S-ITS2 region (Vierna et al. 2010). The 5S rDNA multigene family is formed by a $5 \mathrm{~S}$ rRNA coding region (corresponding to 120 nucleotides of the mature RNA) and a variable in length NTS. The 5S rDNA is characterised by a flexible organisation, as it has been found in clusters composed of similar or divergent tandemly arranged repeats (differences mainly occur in the NTS) and in clusters of 5S rDNA repeats tandemly linked to other multigene families. A dispersed organisation of $5 \mathrm{~S}$ rDNA has also been reported, and some species were found to have more than one type of organisation within the genome (Vierna et al. 2011 and references therein). The ITS1-5.8-ITS2 and 5S rDNA regions have been studied in terms of evolutionary genetics in some Ensis species (Vierna et al. 2009, 2010, 2011). Vierna et al. (2010) concluded that the long-term evolution of these multigene families could be reconciled under a mixed process of concerted evolution, birth-and-death evolution and purifying selection, despite the different levels of intragenomic divergence detected (much higher within the 5S rDNA region). These authors suggested that these differences may be the consequence of a differential genomic organisation of the multigene families, that is, one or few 18S-ITS1-5.8ITS2-28S loci containing several repeats and many $5 \mathrm{~S}$ rDNA loci containing less repeats. Even though no conclusive data is available, our study supports their hypothesis, since the different intensities of FISH signals recorded may be explained by these differences in genomic organisation: we may have obtained weak (or none) $5 \mathrm{~S}$ rDNA FISH signals because the repeats of this multigene family may be very dispersed within the genomes of Ensis species.

Finally, the hybridisation of the vertebrate telomere probe to termini of $E$. minor and $E$. directus chromosomes indicates that the vertebrate (TTAGGG) 22 sequence is present within the genomes of E. minor and E. directus, as was previously detected for the Heterodonta species D. trunculus (Plohl et al. 2002), M. mercenaria and M. lateralis (Wang and Guo 2001), D. exoleta (Hurtado and Pasantes 2005) and T. rhomboides and V. aurea (Carrilho et al. 2011).

In conclusion, this study provides new information on bivalve karyotypes, reveals important differences between American and European Ensis at the chromosome level, confirms E. minor and E. siliqua as separate species and supports a more dispersed organisation of the 5S rDNA compared to the major ribosomal genes.

Acknowledgments We are very grateful to Rudo von Cosel for his support on Ensis taxonomy. VR is supported by a "FPU" fellowship from Ministerio de Educación y Ciencia (Spain), and JV by a "María Barbeito" fellowship from Xunta de Galicia (Spain). This work was funded by the Spanish Ministerio de Educación y Ciencia (CTM200728919-E/MAR). Finally, we would like to thank two anonymous reviewers that greatly improved the quality of this article with their comments.

\section{References}

Borsa P, Thiriot-Quievreux C (1990) Karyological and allozymic characterization of Ruditapes philippinarum, $R$. aureus and $R$. decussatus (Bivalvia, Veneridae). Aquaculture 90:209-227

Carrilho J, Pérez-García C, Leitao A, Malheiro I, Pasantes JJ (2011) Cytogenetic characterization and mapping of rDNAs, core histone genes and telomeric sequences in Venerupis aurea and Tapes rhomboides (Bivalvia: Veneridae). Genetica 139:823-831

Chen X, Gao C, Wang J, Su Y (2008) Study on the karyotypes of Solen linearis. J Xiamen Univ 47:733-735

Cornet M, Soulard C (1989) Number and morphology of the metaphase mitotic chromosomes in Scrobicularia plana (Da Costa, 1778) (Mollusca, Bivalvia, Tellinacea). Caryologia 42:11-18

Corni MG, Trentini M (1986) A chromosomic study of Chamelea gallina (L.) (Bivalvia, Veneridae). Boll Zool 53:23-24

Cosel R (2009) The razor shells of the eastern Atlantic, part 2. Pharidae II: the genus Ensis Schumacher, 1818 (Bivalvia, Solenoidea). Basteria 73:1-48

Cosel R, Dörjes J, Mühlenhardt-Siegel U (1982) Die amerikanische schwertmuschel Ensis directus (Conrad) in der Deutschen Bucht. I. Zoogeographie und taxonomie mi vergleich mit den einheimischen schwertmuschel-Arten. Senckenberg. Marit 14:147-173

Cross I, Díaz E, Sánchez I, Rebordinos L (2005) Molecular and cytogenetic characterization of Crassostrea angulata chromosomes. Aquaculture 247:135-144

Ebied AM, Aly FM (2004) Cytogenetic studies on metaphase chromosomes of six bivalve species of families Mytilidae and Veneridae (Nucinelloidea, Mollusca). Cytologia 69:261-273

Fernández-Tajes J, González-Tizón A, Martínez-Lage A, Méndez J (2003) Cytogenetics in the razor clam Solen marginatus (Mollusca: Bivalvia: Solenidae). Cytogenet. Genome Res 101: 43-46

Fernández-Tajes J, Martínez-Lage A, Freire R, Guerra A, Méndez J, González-Tizón A (2008) Genome sizes and karyotypes in the razor clams Ensis arcuatus (Jeffreys, 1865) and E. siliqua (Linnaeus, 1758). Cah Biol Mar 49:79-85

González-Tizón A, Martíne-Lage A, Rego I, Ausió J, Méndez J (2000) DNA content, karyotype and chromosomal location of 
18S-5.8S-28S ribosomal loci in some species of bivalve mollusc from the Pacific Canadian coast. Genome 43:409-411

Huang X, Hu X, Hu J, Zhang L, Wang S, Lu W, Bao Z (2007a) Mapping of ribosomal DNA and (TTAGGG) $)_{\mathrm{n}}$ telomeric sequence by FISH in the bivalve Patinopecten yessoensis (Jay, 1957). J Moll Stud 73:393-398

Huang X, Hu J, Hu X, Zhang G, Zhang L, Wang S, Lu W, Bao Z (2007b) Cytogenetic characterization of the bay scallop, Argopecten irradians irradians, by multiple staining techniques and fluorescence in situ hybridization. Genes Genet Sys 82:257-263

Hurtado NS, Pasantes JJ (2005) Surface spreading of synaptonemal complexes in the clam Dosinia exoleta (Mollusca, Bivalvia). Chromosome Res 13:575-580

Insua A, Thiriot-Quievreux C (1992) Karyotypes of Cerastoderma edule, Venerupis pullastra and Venerupis rhomboides (Bivalvia, Veneroida). Aquat Living Resour 5:1-8

Insua A, Freire R, Méndez J (1999) The 5S rDNA of the bivalve Cerastoderma edule: nucleotide sequence of the repeat unit and chromosomal location relative to $18 \mathrm{~S}-28 \mathrm{~S}$ rDNA. Genet Sel Evol 31:509-518

Iqbal ANMZ, Khan MS, Goswami U (2008) Cytogenetic studies in green mussel, Perna viridis (Mytiloida: Pteriomorphia), from west coast of India. Mar Biol 153:987-993

Leitao A, Chaves R, Matias D, Joaquim S, Ruano F, Guedes-Pinto H (2006) Restriction enzyme digestion chromosome banding on two commercially important veneroid bivalve species: Ruditapes decussatus and Cerastoderma edule. J Shell Res 25:857-864

Levan A, Fredga K, Sandberg AA (1964) Nomenclature for centromeric position on chromosomes. Hereditas 52:201-220

López-Piñón MJ, Insua A, Méndez J (2005) Chromosome analysis and mapping of ribosomal genes by one-and two-color fluorescent in situ hybridization in Hinnites distortus (Bivalvia: Pectinidae). J Hered 96:52-58

Martínez A, Mariñas L, González-Tizón A, Méndez J (2002) Cytogenetic characterization of Donax trunculus (Bivalvia: Donacidae) by means of karyotyping, fluorochrome banding and fluorescent in situ hybridization. J Moll Stud 68:393-396

Martínez-Lage A, Rodríguez-Fariña F, González-Tizón A, Prats L, Cornudella L, Méndez J (2002) Comparative analysis of different satellite DNAs in four mussel Mytilus species. Genome 45:922-929

Odierna G, Aprea G, Barucca M, Canapa A, Capriglione T, Olmo E (2006) Karyology of the Antarctic scallop Adamussium colbecki, with some comments on the karyological evolution of pectinids. Genetica 127:341-349

Ó Foighil D, Thiriot-Quievreux C (1999) Sympatric Australian Lasaea species (Mollusca: Bivalvia) differ in their ploidy levels, reproductive modes and developmental modes. Zool J Linn Soc 127:477-494

Pauls E, Afonso PR (2000) The karyotypes of nodipecten nodosus (Bivalvia: Pectinidae). Hydrobiologia 420:99-102

Pérez-García C, Guerra-Varela J, Morán P, Pasantes JJ (2010) Chromosomal mapping of rRNA genes, core histone genes and telomeric sequences in Brachidontes puniceus and Brachidontes rodriguezi (Bivalvia, Mytilidae). BMC Genet 11:109-117

Pérez-García C, Morán P, Pasantes JJ (2011) Cytogenetic characterization of the invasive mussel species Xenostrobus securis Lmk. (Bivalvia: Mytilidae). Genome 54:771-778

Petkeviciute R, Stunzenas V, Staneviciute G (2006) Polymorphism of the Sphaerium corneum (Bivalvia, Veneroida, Sphaeriidae) revealed by cytogenetic and sequence comparison. Biol J Linn Soc 89:53-64

Plohl M, Prats E, Martínez-Lage A, González-Tizón A, Méndez J, Cornudella L (2002) Telomeric localization of the vertebratetype hexamer repeat (TTAGGG) $n$, in the wedgeshell clam Donax trunculus and other marine invertebrate genomes. J Biol Chem 277:19839-19846
Roiha H, Miller JR, Woods LC, Glower DM (1981) Arrangements and rearrangements of sequences flanking the two types of rDNA insertion in D. melanogaster. Nature 290:749-753

Sun Z, Shao Y, Guo S, Qin Y (2003) Karyotypes of three species of marine Veneroida molluscs. Acta Oceanol Sin 22:671-678

Thiriot-Quievreux C (1992) Karyotype of Lasaea australis, a brooding bivalve species. Aust J Mar Freshw Res 43:403-408

Thiriot-Quievreux C, Soyer J, Bouvy M, Allen JA (1988a) Chromosomes of some subantarctic brooding bivalve species. Veliger 30:248-256

Thiriot-Quievreux C, Soyer J, Bovee F, Albert P (1988b) Unusual chromosome complement in the brooding bivalve Lasaea consanguinea. Genetica 75:143-151

Thiriot-Quievreux C, Insua A, Albert P (1989) Polyploidie chez un bivalve incubant, Lasaea rubra (Montagu). C R Acad Sci Paris 308:115-120

Thiriot-Quievreux C, Albert P, Soyer J (1990) Karyotypes of five subantarctic bivalve species. J Molluscan Stud 57:59-70

Varela MA, González-Tizón A, Francisco-Candeira M, MartínezLage A (2007) Isolation and characterization of polymorphic microsatellite loci in the razor clam Ensis siliqua. Mol Ecol Notes 7:221-222

Varela MA, Martínez-Lage A, González-Tizón A (2009) A Temporal genetic variation of microsatellite markers in the razor clam Ensis arcuatus (Bivalvia: Pharidae). J Mar Biol Assoc UK 89:1703-1707

Vierna J, González-Tizón A, Martínez-Lage A (2009) Long-term evolution of $5 \mathrm{~S}$ ribosomal DNA seems to be driven by birth-anddeath processes and selection in Ensis razor shells (Mollusca: Bivalvia). Biochem Genet 47:635-644

Vierna J, Martínez-Lage A, González-Tizón A (2010) Analysis of ITS1 and ITS2 sequences in Ensis razor shells: suitability as molecular markers at the population and species levels, and evolution of these ribosomal DNA spacers. Genome 53:23-34

Vierna J, Jensen KT, Martínez-Lage A, González-Tizón A (2011) The linked units of 5S rDNA and U1 snDNA of razor shells (Mollusca: Bivalvia: Pharidae). Heredity 107:127-142

Vitturi R, Maiorca A, Catalano E (1983) The karyology of Teredo utriculus (Gmelin) (Mollusca, Pelecypoda). Biol Bull 165:450-457

Vitturi R, Gianguzza P, Colomba MS, Riggio S (2000) Cytogenetic characterization of Brachidontes pharaonis (Fisher P., 1870): karyotype, banding and fluorescence in situ hybridization (FISH) (Mollusca: Bivalvia: Mytilidae). Ophelia 52:213-220

Wang Y, Guo X (2001) Chromosomal mapping of the vertebrate telomeric sequence (TTAGGG)n in four bivalve molluscs by fluorescent in situ hybridization. J Shell Res 20:1187-1190

Wang Y, Guo X (2004) Chromosomal rearrangement in Pectinidae revealed by rRNA loci and implications for bivalve evolution. Biol Bull 207:247-256

Wang Y, Guo X (2007) Chromosomal mapping of major ribosomal rRNA genes in the hard clam (Mercenaria mercenaria) using fluorescence in situ hybridization. Mar Biol 150:1183-1189

Wang Y, Guo X (2008) Chromosomal mapping of the major ribosomal RNA genes in the dwarf surfclam (Mulinia lateralis Say). J Shell Res 27:307-311

Wang J, Zhao X, Zhou L, Xiang J (1998) Chromosome study of Sinonovacula constricta (Bivalvia). Oceanol Limnol Sin 29:191-196

Wang L, Xiang J, Zhou L (2001) Chromosome study of Cyclina sinensis Gmelin. J Northwest Sci Tech Univ Agric For 29:94-96

Wang Y, Xu Z, Guo X (2005a) Chromosomal mapping of 5S ribosomal RNA genes in the Eastern oyster, Crassostrea virginica Gmelin by fluorescence in situ hybridization. J Shell Res 24:959-964

Wang Y, Xu Z, Pierce JC, Guo X (2005b) Characterization of eastern oyster (Crassostrea virginica Gmelin) chromosomes by 
fluorescence in situ hybridization with bacteriophage P1 clones. Mar Biotech 7:207-214

White MJD (1978) Modes of speciation. WH Freeman, San Francisco

Wu P, Dong J, Ni J, Chong J (2002) The study on chromosomes of Meretrix meretrix. J Shanghai Fish Univ. doi:1004-7271.0.200202-002

Xu Z, Guo X, Gaffney PM, Pierce JC (2001) Chromosomal location of the major ribosomal RNA genes in Crassostrea virginica and C. gigas. Veliger 44:79-83
Zhang L, Bao Z, Wang J, Wang S, Huang X, Hu X, Hu J (2007) Cytogenetic analysis in two scallops (Bivalvia: Pectinidae) by PRINS and PI banding. Acta Oceanol Sin 26:153-157

Zhang L, Bao Z, Wang S, Hu X, Hu J (2008) FISH mapping and identification of zhikong scallop (Chlamys farreri) chromosomes. Mar Biotech 10:151-157 